\title{
SPATIAL DIVERSIFICATION OF BEE (HYMENOPTERA: APOIDEA: APIFORMES) ASSEMBLAGES IN FOREST COMMUNITIES OF THE SUCHEDNIÓW-OBLĘGOREK LANDSCAPE PARK
}

\author{
Jolanta Bąk-Badowska \\ Institute of Biology, Jan Kochanowski University, \\ ul. Świętokrzyska 15, 25-406 Kielce, Poland. \\ e-mail: jolanta.bak@ujk.edu.pl \\ Received 01 August 2012; accepted 29 October 2012
}

\section{$\mathrm{S}$ u m m a r y}

The aim of the study, carried out from April to October in 2004 and 2005, was to characterise bee (Apiformes) assemblages in the phytosociologically diversified forest communities of the Suchedniów-Oblęgorek Landscape Park. Moericke colour traps were used to capture the bees. The five study sites yielded 76 bee species. There was a predominance of representatives from the families Apidae (28 species, 900 individuals) and Andrenidae (20 species, 222 individuals). The indices of species diversity $\left(\mathrm{H}^{\prime}\right)$ and evenness $(\mathrm{J}$ ') reached their highest values in a mixed coniferous forest (BM) site, and reached their lowest values in a fir forest (BJ) site. Qualitative and quantitative similarity of assemblage structure was highest in assemblages in mixed coniferous forest, mesic coniferous forest, and oak-hornbeam forest habitats, decreasing in floristically poor habitats not favourable to nesting, i.e. fir forest and riparian forest. Traps placed on the forest floor in ground cover contained more individuals and species of bees, with 1192 individuals $(88.8 \%)$ and 76 species, than in the canopy layer, with 150 individuals $(11.2 \%)$ and 23 species. This trend was consistent across all the habitats in the Landscape Park.

Keywords: Apiformes, assemblage structure, forest habitats, vertical distribution, Suchedniów-Oblęgorek Landscape Park.

\section{INTRODUCTION}

Bees have been relatively well studied in Poland, with most research focusing on open areas such as meadows, fields, and xerothermal grasslands, which are populated by particularly abundant bee assemblages (Dylewska and Noskiewicz, 1963; Dylewska, 1966; Banaszak and Plewka, 1981; Pawlikowski, 1985; Oertli et al., 2005). Forest areas were formerly believed to not be very attractive to bees. It was only in the early 1980's that interest in the presence of bees in forests began to grow. Existing studies have taken into account not only those species associated with plants found on the forest floor in ground cover, but also those captured in tree canopies (Pawlikowski, 1985, 1990; Banaszak,
1987, 1990; Banaszak and Cierzniak, 1994; Krzysztofiak, 2001; Cierzniak, 2003; Banaszak and Jaroszewicz, 2009; Tuell and Isaacs, 2009).

Bees' natural resources depend on several factors, both natural and anthropogenic, including habitat type, moisture levels and fertility, and the resulting diversity of plant communities. Research by Pawlikowski (1992) and Krzysztofiak (2001) showed that the species richness and diversity of bees in the forest decrease as the forest stand grows older. There are also changes in habitat conditions. These changes are mostly owing to decreased availability of food plants and nesting sites as individual layers of forest vegetation contribute to a habitat's microclimate. The amplitude of changes in temperature and moisture levels are reduced. 
One effective way to preserve the biological diversity of insects, including bees, is to protect species in their natural habitats. Accordingly, studies of areas that have suffered the least anthropogenic impact, such as national parks, nature reserves and landscape parks are particularly valuable.

Despite many years of research on the structure of bee assemblages in the Małopolska Upland, data on this insect group are still incomplete. As part of investigations of bees of protected areas within the Upland, a study was conducted to characterise bee assemblages in phytosociologically diversified forest communities of the Suchedniów-Oblęgorek Landscape Park (S-OLP). An earlier study from 1999-2000, carried out in three types of phytocoenosis in the Park, was only concerned with the Bombus species (Bąk, 2003).

\section{Area of study}

Suchedniów-Oblęgorek Landscape Park is located in the Małopolska Upland in the macroregion of the Kielce Upland (Kondracki, 2002) to the north of the town of Kielce. The Świętokrzyski (Holy Cross) National Park is the border in the north-west. It is the largest landscape park in the Małopolska Upland, covering an area of 21407 ha (Fig. 1). The park consists of two separate areas surrounded by one protection zone with an area of 25681 ha. The eastern part, known as the Suchedniów area, is covered with mixed forests and embraces the Suchedniów Plateau and the Kołomań Hills. The western park, the Oblęgorek area, includes the Oblęgorek Range of the Holy Cross Mountains.

The entire area of the Park is part of a climatic unit called Holy Cross Upland by Romer (1949). The climatic conditions here change with altitude above sea level. Mean annual ambient air temperature in the Park does not vary much, ranging from $6.8^{\circ} \mathrm{C}$ to $7.6^{\circ} \mathrm{C}$. The highest precipitation is in June (100 mm), July (99 $\mathrm{mm})$, and August $(73 \mathrm{~mm})$, with a mean annual total precipitation between $600 \mathrm{~mm}$ and $770 \mathrm{~mm}$.
The dominant type of soil is podzolic soil with a shallow humus horizon. This soil is mostly found on the slopes of hummocks and in river floodplains. The soil is stony and considerably acidified.

The greatest natural asset of the Park is its forests, which occupy nearly $90 \%$ of its area. These forests are what has remained of a large and mostly natural forest complex called Holy Cross Primeval Forest. The dominant forest type is a fertile mixed coniferous forest, with smaller areas supporting oak-hornbeam forests, ash-aspen riparian forests, swamp forest, and the Carpathian beechwood. The most important forest-forming tree species are pine $(52 \%)$ and fir $(31 \%)$.

Study sites were set up in the Park in a variety of forest habitat types. They are presented in Fig. 1 against the UTM square grid (Enghoff and Nielsen, 1978).

Site 1, UTM: DB75; Zagnańsk Forest Inspectorate, Bartków forest district, division 77

This site is made up of a mixed coniferous forest (BM) (Querco roboris-Pinetum). The stand is $60-70$ years old. The tallest layer of trees is made up of Quercus robur and Pinus sylvestris. Under the tallest layer there is a sub-canopy layer, formed mainly of Pinus sylvestris, Quercus robur and Carpinus betulus. The shrub layer has a of $30 \%$ density. This layer is dominated by Quercus robur, Frangula alnus and Corylus avellana. The herb layer is not dense $(50 \%)$ and is strongly shaded, with Vaccinium myrtillus, Anemone nemorosa, Convallaria majalis, Melampyrum nemorosum, Hieracium sp. and others. A total of 48 species of vascular plants were found at this site.

Site 2, UTM: DB75; Suchedniów Forest Inspectorate, Wilczy Bór forest district, division 100

This is the site of the mesic coniferous forest (BS) (Leucobryo-Pinetum). The forest stand is 60 years old and has a density of $60 \%$, with a predominance of Pinus sylvestris and Betula pendula. The understorey is $10 \%$, consisting mainly of Quercus robur, and more rarely Sorbus 


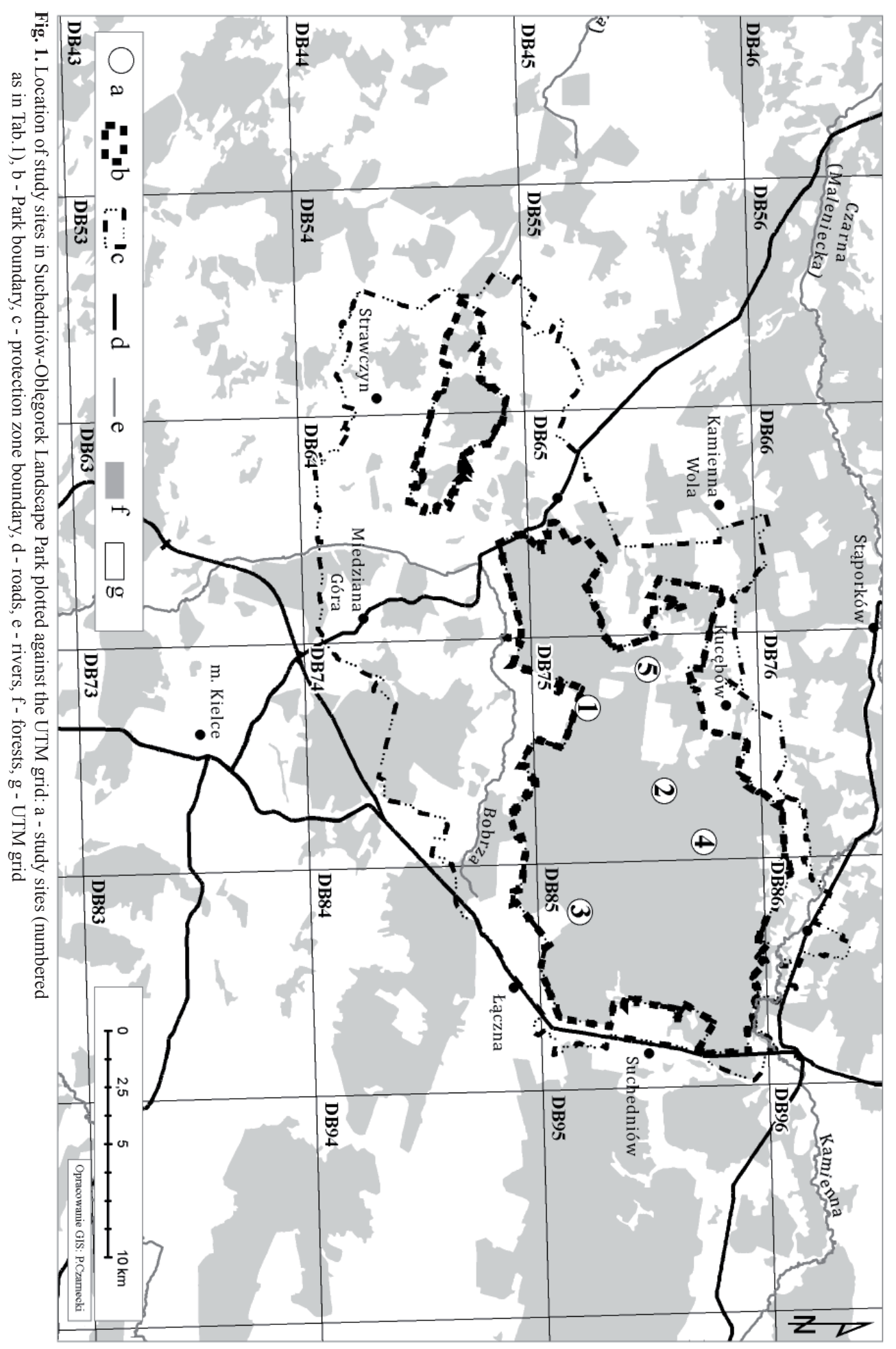


aucuparia, Pinus sylvestris and Betula pendula. The herb layer is of $70 \%$ density. It is made up of Vaccinium myrtillus, Vaccinium vitis-idaea, Melampyrum pratense, Calluna vulgaris, Carex pilulifera and others. The number of vascular plant species identified was 39 .

Site 3, UTM: DB85; Suchedniów Forest Inspectorate, Osieczno forest district, division 107

This is the site is of the oak-hornbeam forest (GR) (Tilio cordatae-Carpinetum betuli). The forest stand is approximately 60 years old. The tallest layer of trees have a $70 \%$ density. The tallest layer is mostly made up of Quercus robur, Betula pendula, Tilia cordata, Carpinus betulus and Populus tremula. A sub-canopy layer is formed of Quercus robur, Carpinus betulus and Fagus sylvatica with a small admixture of Abies alba. The understory is dominated by Carpinus betulus, Abies alba and Corylus avellana. The shrub layer density reaches $40 \%$. The herb layer, of low density and heavy shading, consists of Anemone nemorosa, Galeobdolon luteum, Hepatica nobilis, Dentaria bulbifera, Viola reichenbachiana, Pulmonaria obscura, Rubus hirtus and others. A total of 32 species of vascular plants were identified.

Site 4, UTM: DB75; Suchedniów Forest Inspectorate, Św. Góra forest district, division 96

This is the site of the fir forest (BJ) (Abietetum polonicum). The tree community is 70 years old, shady, with a five-layer structure. In the tree and shrub layer, the dominant species is Abies alba. Another species in the tree layer is Fagus sylvatica. This species has a $80 \%$ density. A sub-canopy layer of $40 \%$ density, is made up of Fagus sylvatica, Abies alba and Carpinus betulus. The understory has a similar density and consists mainly of Abies alba and Carpinus betulus, with a smaller contribution of Sorbus aucuparia. The herb layer consists of: Maianthemum bifolium, Oxalis acetosella, Luzula pilosa and Vaccinium myrtillus. The number of vascular plant species identified was 24 .
Site 5, UTM: DB75; Zagnańsk Forest Inspectorate, Bartków forest district, division 119

This is the site of the riparian forest complex (LG) (Fraxino-Alnetum) on humic, very moist soils. The forest stand is approx. 50 years old and is made up of Alnus glutinosa. The understorey has a $40 \%$ density, with a predominance of Alnus glutinosa and Corylus avellana. The herb layer, of $90 \%$ density, consists of hygrophilous and umbrophilous species, such as Filipendula ulmaria, Crepis paludosa, Lycopus europaeus, Galium palustre, Peucedanum palustre and others. A total of 26 species of vascular plants were identified within this site.

\section{MATERIAL AND METHODS}

Bee assemblages of selected sites in the Suchedniów-Oblęgorek Landscape Park were studied from April to October in 2004 and 2005. Bees were collected from Moericke colour traps (Moericke, 1951). The capture data were used to study the vertical distribution of the insects in different forest habitats. The colour trap method also provides data on the species composition of bee assemblages and the patterns of the appearance of individual species.

The Moericke colour traps used in this study were white plastic vessels, $20 \mathrm{~cm}$ in diameter and $15 \mathrm{~cm}$ deep, half-filled with a liquid composed of $95 \%$ water, $4.8 \%$ ethylene glycol and $0.2 \%$ surfactant. Three traps were placed on each site in two layers of forest: in the ground cover layer on the ground, and in tree canopies at a height of 10-12 m. Insects captured were removed and the liquid replaced at two-week intervals.

Insects collected over 14 days represented one sample. All samples were used to determine the structure of the bee assemblages. A bee assemblage is defined here as a group of species co-existing in a given area. It consists of species that nest in the area and those which fly in from adjacent areas to search for food. It was assumed that bees captured in traps 


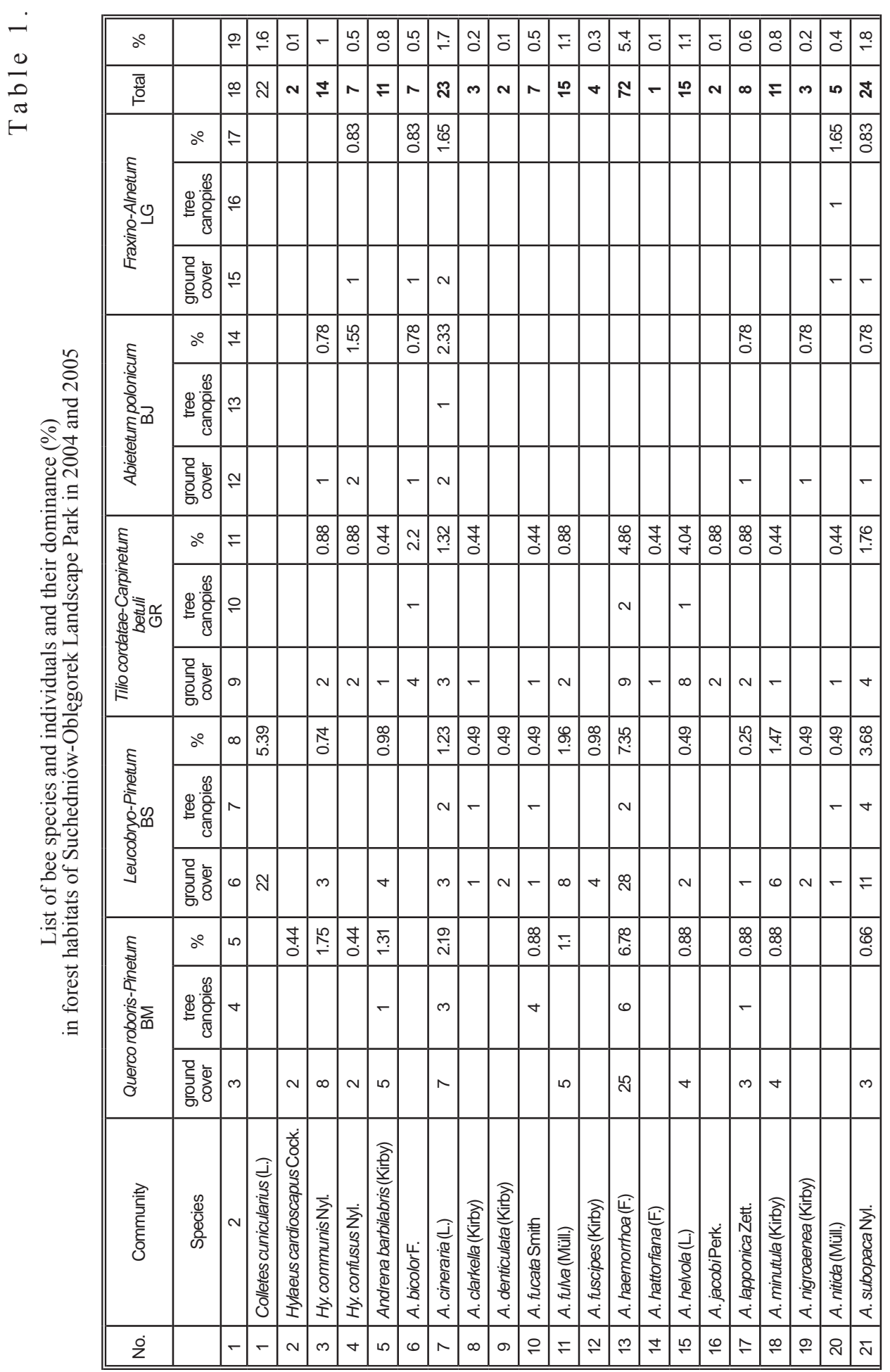




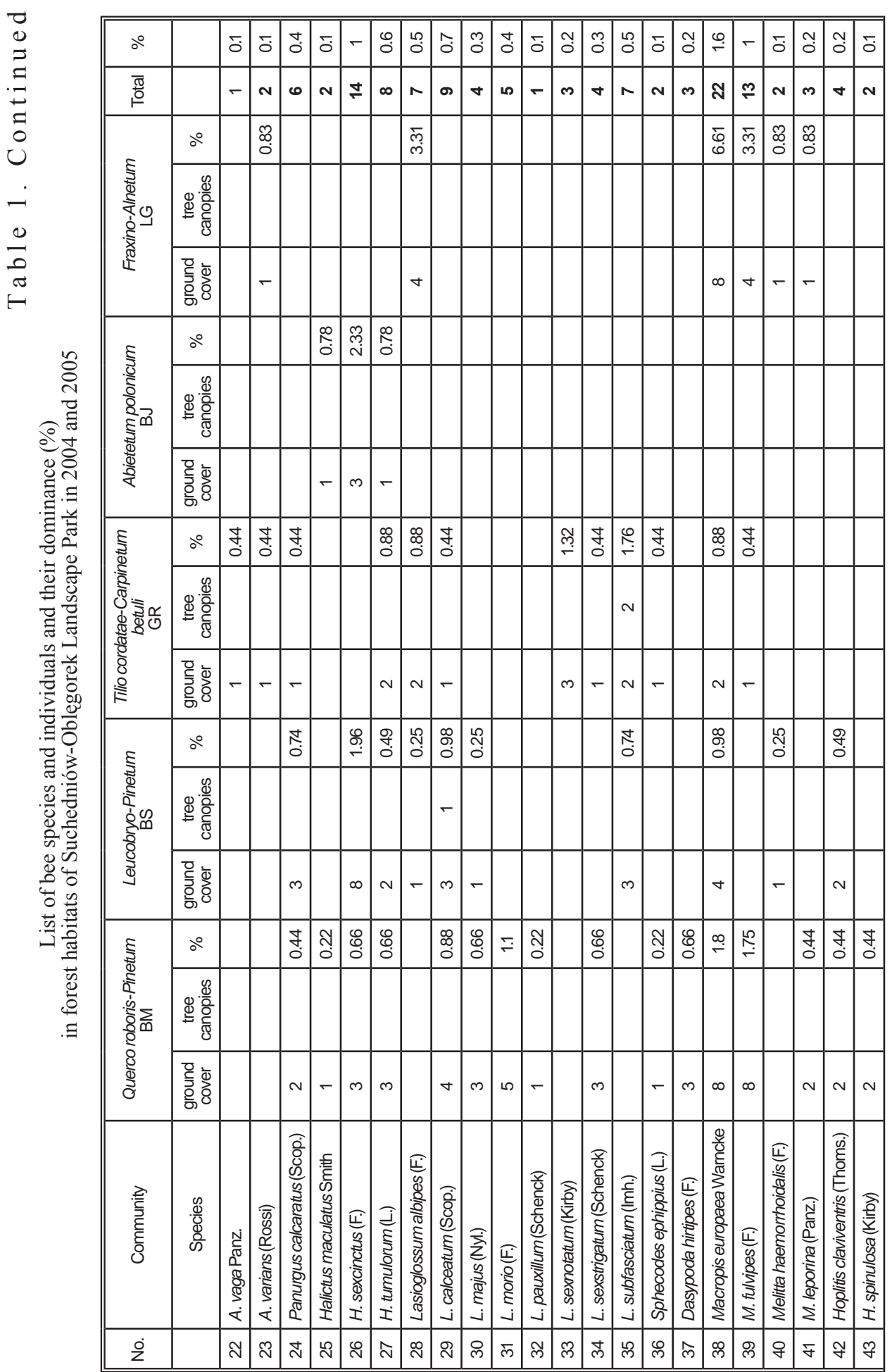




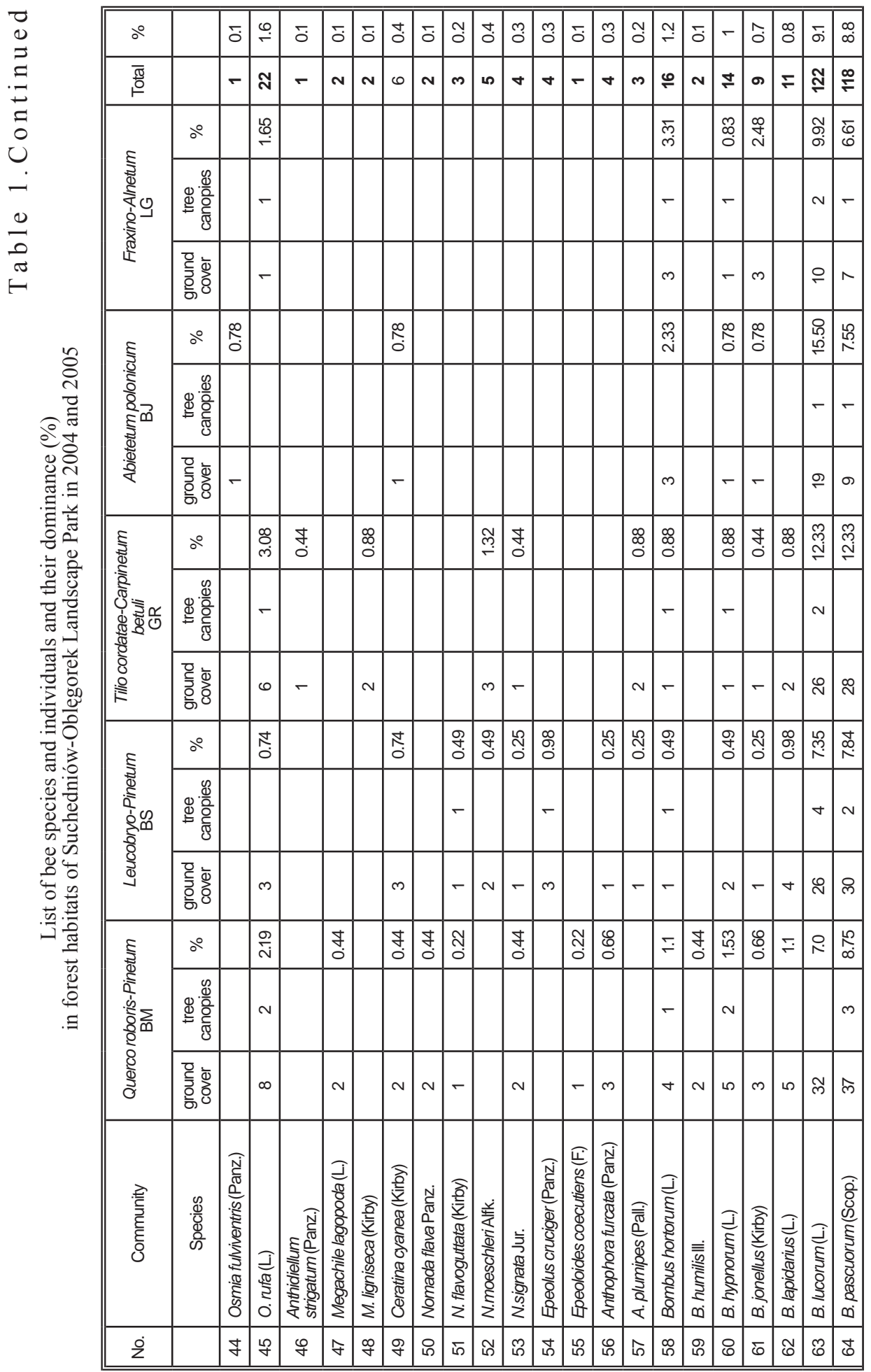




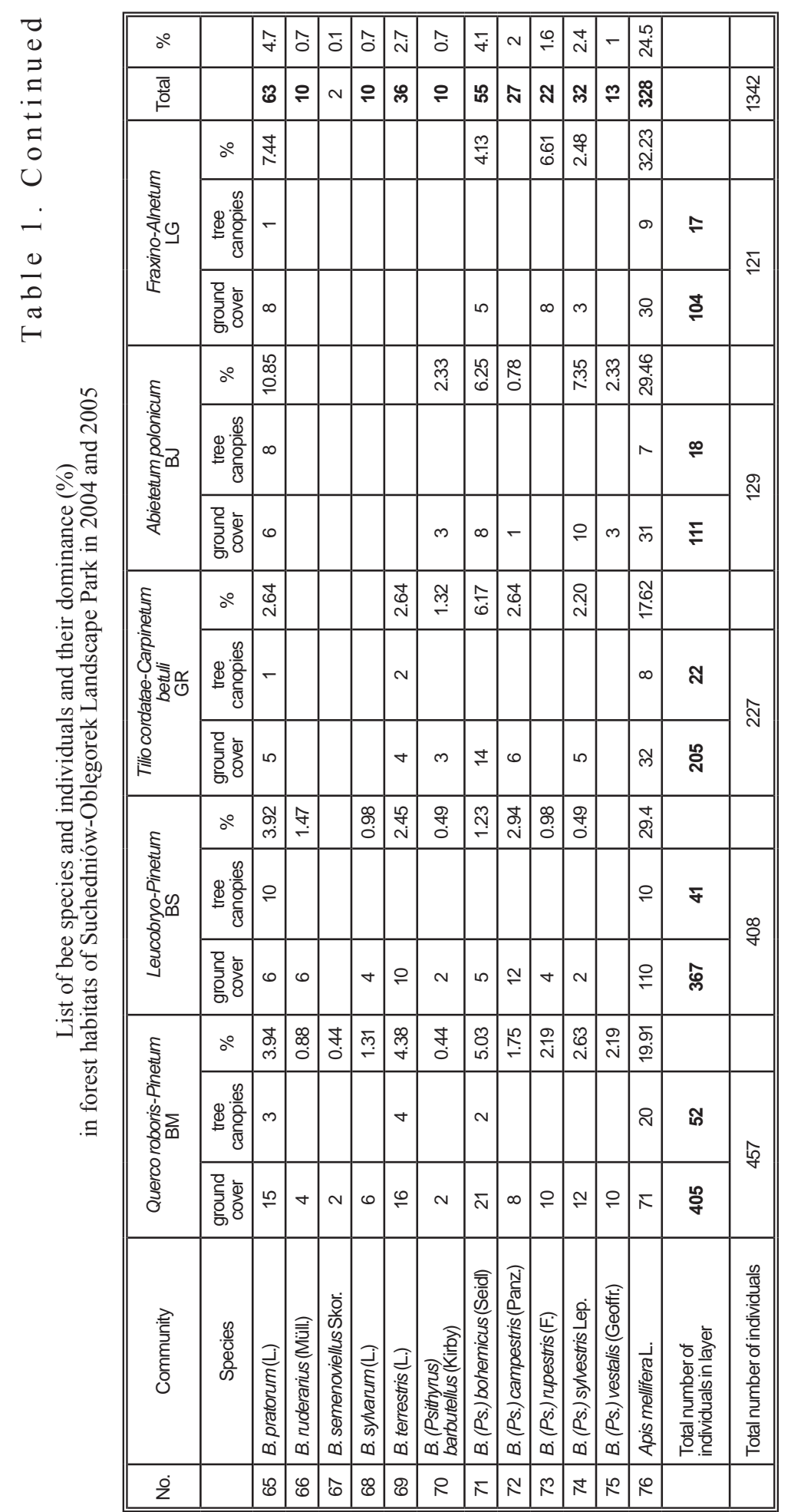


placed on the ground penetrated the part of the ground cover just above the ground and low-growing herbs, while bees found in the traps hung at 10-12 m above ground penetrated the topmost layer of tree canopies.

The structure of each assemblage was described with the number of samples (n), the number of species (S), the number of individuals $(\mathrm{N})$, an index of dominance (D), an index of general diversity (H') (Shannon and Weaver, 1963), and an index of evenness (J') (Pielou, 1966).

Descriptive dominance classes, after Witkowski (1975), were as follows: eudominants $>10.0 \%$ of all specimens; dominants $\quad 5.1-10.0 \%$; subdominants $2.1-5.0 \%$; recedents $1.1-2.0 \%$; and subrecedents $\leq 1.0 \%$.

Qualitative comparisons of assemblages were based on the MarczewskiSteinhaus index (Marczewski and Steinhaus, 1959);

$$
\mathrm{MS}=100 \mathrm{c} / \mathrm{a}+\mathrm{b}-\mathrm{c} \text {, }
$$

where $a$ is the number of species in one assemblage, $b$ is the number of species in another assemblage, and $\mathrm{c}$ is the number of species common to both assemblages.

Qunatitative comparisons were based on Renkonen's index (1938);

$$
\operatorname{Re}=\Sigma \mathrm{D}_{\min },
$$

where $\mathrm{D}_{\min }$ is the lowest value of minimum dominance of a species in the assemblages being compared.

The systematic division and ordering of bees were given after Michener (2007), the nomenclature of bee species was given after Ruszkowski and Ruszkowski
(1998) and Banaszak (2004). The nomenclature of plant species was given after Mirek et al. (2002). The specimens were determined by the author.

\section{RESULTS}

A total of 1342 bee individuals representing 76 species and 6 families were captured in Moericke traps during the two years of the study. The dominant bee families in the five study sites were Apidae (69.4\%) and Andrenidae (16.5\%). There were few representatives of Colletidae (3.4\%) and Melittidae (3.2\%) (Tab. 1). The most abundant genera were Bombus and Andrena. An analysis of the number of species representing individual families found that the Apidae (28 species) and Andrenidae (20 species) families were most numerous, and Colletidae (4 species) and Melittidae (5 species) were least numerous, the two remaining families being represented by 12 species (Halictidae) and 7 species (Megachilidae) (Tab. 2). The dominant species were Apis mellifera $(24.5 \%)$, Bombus lucorum (9.1\%), B. pascuorum (8.8\%) and Andrena haemorrhoa (5.4\%) (Tab. 1).

Each forest habitat supported a structurally different bee assemblage.

$$
\text { Querco roboris-Pinetum, mixed }
$$

\section{coniferous forest (BM)}

The bee assemblage in the study site was composed of 55 species (457 individuals) (Tab. 1, 3), with a predominance of representatives from the families Apidae and Andrenidae, whose individuals accounted for $82.5 \%$ of the assemblage.

Table 2 .

\begin{tabular}{|c|c|c|c|c|c|c|c|c|c|c|c|}
\hline Community & \multicolumn{2}{|c|}{$\mathrm{BM}$} & \multicolumn{2}{|c|}{$\mathrm{BS}$} & \multicolumn{2}{|c|}{ GR } & \multicolumn{2}{|c|}{$\mathrm{BJ}$} & \multicolumn{2}{|c|}{ LG } & Total \\
\hline Family & $\begin{array}{c}\text { ground } \\
\text { cover }\end{array}$ & $\begin{array}{c}\text { tree } \\
\text { canopies }\end{array}$ & $\begin{array}{c}\text { ground } \\
\text { cover }\end{array}$ & $\begin{array}{c}\text { tree } \\
\text { canopies }\end{array}$ & $\begin{array}{l}\text { ground } \\
\text { cover }\end{array}$ & $\begin{array}{c}\text { tree } \\
\text { canopies }\end{array}$ & $\begin{array}{c}\text { ground } \\
\text { cover }\end{array}$ & $\begin{array}{c}\text { tree } \\
\text { canopies }\end{array}$ & $\begin{array}{c}\text { ground } \\
\text { cover }\end{array}$ & $\begin{array}{c}\text { tree } \\
\text { canopies }\end{array}$ & \\
\hline Colletidae & 3 & - & 2 & - & 2 & - & 2 & - & 1 & - & 4 \\
\hline Andrenidae & 9 & 5 & 15 & 6 & 17 & 3 & 5 & 1 & 5 & 1 & 20 \\
\hline Halictidae & 9 & - & 6 & 1 & 7 & 1 & 3 & - & 1 & - & 12 \\
\hline Melittidae & 4 & - & 2 & - & 2 & - & - & - & 4 & - & 5 \\
\hline Megachilidae & 4 & 1 & 2 & - & 3 & 1 & 1 & - & 1 & 1 & 7 \\
\hline Apidae & 25 & 7 & 23 & 7 & 16 & 6 & 13 & 4 & 10 & 6 & 28 \\
\hline
\end{tabular}

Number of bee species from individual families captured into Moericke's traps in the ground cover and canopy layer of forest habitats in S-OLP 
The highest value of the index of species diversity ( $\left.\mathrm{H}^{\prime}\right)$ was 4.75 , and the index of evenness (J') was 0.76 (Tab. 3 ).

Ground cover - A total of 54 species (405 individuals) were captured in ground cover of the mixed coniferous forest site (Tab. 3). The family Apidae was most numerous in terms of both the number of species and individuals (25 species, 276 individuals), and was followed by Andrenidae (9 species, 58 individuals) and Halictidae (9 species, 24 individuals) (Tab. 1, 2). The most abundant species were Apis mellifera (17.5\%), Bombus pascuorum (9.4\%), B. lucorum $(7.9 \%)$ and B. bohemicus (5.2\%). The only numerous representative of Andrenidae was Andrena haemorrhoa (6.2\%) (Fig. 2). The H' index reached a maximum value of 4.83 in this layer, and the J' index was 0.84 (Tab. 3).

Tree canopies - There were 52 individuals representing 13 species captured in the tree canopies (Tab. 3). There were no species from the families Colletidae, Halictidae or Melittidae (Tab. 2), while Apidae (7 species, 35 individuals) and Andrenidae
(5 species, 15 individuals) bees were numerous (Tab. 1, 2). The dominant species in this layer were Apis mellifera (37\%), Andrena fucata (7.7\%), Bombus terrestris (7.7\%), A. cineraria, B. pascuorum and B. pratorum (5.8\% each) (Fig. 2). The $\mathrm{H}^{\prime}$ index of species diversity was 3.04 , and the $\mathrm{J}$ ' index of evenness was 0.82 (Tab. 3 ).

Leucobryo-Pinetum, mesic coniferous forest (BS)

Traps in this habitat yielded 408 individuals belonging to 50 species (Tab. 1, 3). The patterns of dominance were similar to those observed in the mixed coniferous forest site, with a predominance of species and individuals from the families Apidae (23 species, 266 individuals) and Andrenidae (15 species, 88 individuals) (Tab. 1, 2). The H' index was 4.27 , and the $\mathrm{J}$ ' index was 0.68 (Tab. 3).

Ground cover - Traps in this layer yielded 50 species and 367 individuals (Tab. 3). The most abundant families were Apidae (23 species, 237 individuals) and Andrenidae (15 species, 77 individuals) (Tab. 1, 2). The dominant species included Apis mellifera (30\%), Bombus pascuorum

Table 3 .

Biocoenotic indices of bee assemblages of forest habitats in S-OLP

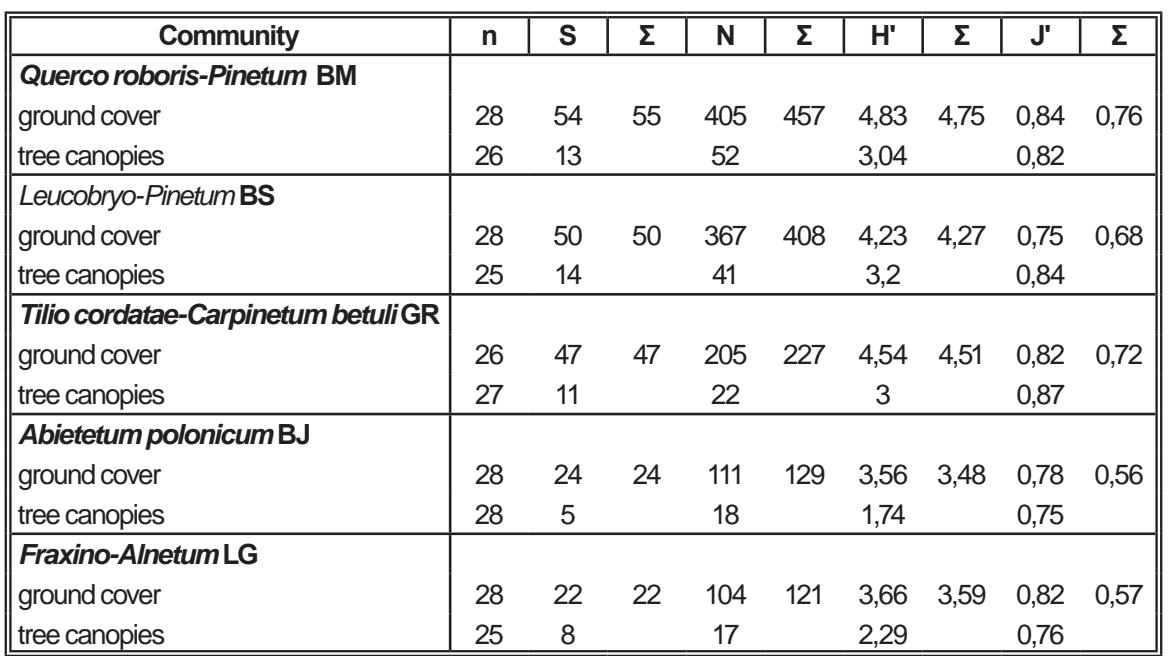

$\mathrm{n}$ - number of samples

$\mathrm{S}$ - number of species

$\mathrm{N}$ - number of individuals

H' - species diversity, based on Shannon and Weaver's formula (1963)

J' - evenness, based on Pielou's formula (1963) 
(8.2\%), and Andrena haemorrhoa (7.6\%). Colletes cunicularius was also numerously collected in late April and early May (Fig. 3). The H' index was 4.23, and the $\mathrm{J}$ ' index was 0.75 (Tab. 3 ).

Tree canopies - Traps in tree canopies yielded 14 species and 41 individuals (Tab. 3). The families Apidae and Andrenidae were represented by 7 and 6 species, respectively, while the only Halictidae species was Lasioglossum calceatum (Tab. 1, 2). Two species: Bombus pratorum and Apis mellifera, reached the highest dominance level ( $24.4 \%$ each), and the group of dominants comprised Andrena subopaca and B. lucorum (9.8\% each) (Fig. 3). The index of species diversity (H') for the bee assemblage of tree canopies was 3.2, and the J' index was 0.84 (Tab. 3).

Tilio cordatae-Carpinetum betuli, oakhornbeam forest (GR)

This habitat supported species from all 6 families recorded in the study area, with 227 individuals belonging to 47 species (Tab. 1, 3). As in the sites described above, the dominant families were Andrenidae (17 species, 47 individuals) and Apidae (16 species, 149 individuals) (Tab. 1, 2). The most numerous genera were Bombus and Andrena, constituting $65.6 \%$ of the assemblage. The values of the $\mathrm{H}^{\prime}$ and $\mathrm{J}$ ' indices were 4.51 and 0.72 , respectively (Tab. 3)
Ground cover - There were 47 species (205 individuals) (Tab. 3). Besides Apis mellifera, the dominant taxa in the lowgrowing herb layer were bumble bees and their parasites (Bombus pascuorum - 13.7\%, B. lucorum - $12.7 \%$ and B. bohemicus $6.8 \%$ ). The remaining 43 species made up $51.2 \%$ of the assemblage (Fig. 4). The $\mathrm{H}$ ' index was 4.54 , and the J' index was 0.82 (Tab. 3).

Tree canopies - This assemblage was made up of 11 species (22 individuals) (Tab. 3). Apis mellifera was a eudominant ( $\mathrm{D}=36.4 \%$ ). Dominants were Andrena haemorrhoa, Lasioglossum subfasciatum, Bombus lucorum and B. terrestris, all with a dominance index of $9.1 \%$ (Fig. 4). The $\mathrm{H}^{\prime}$ and $\mathrm{J}$ ' indices amounted to 3.0 and 0.87 , respectively (Tab. 3).

Abietetum polonicum, fir forest (BJ)

In the fir forest, the bee assemblage was made up of 129 individuals belonging to 24 species (Tab. 1, 3). There were no species from the family Melittidae. The most numerous family was the Apidae, with 13 species and 111 individuals) (Tab. $1,2)$. The values of the $H^{\prime}$ and $J$ ' indices were the lowest compared to the other study sites, at 3.48 and 0.56 , respectively (Tab. 3).

Ground cover - In the low-growing herb layer, Moericke traps yielded 111 individuals of 24 species (Tab. 3).
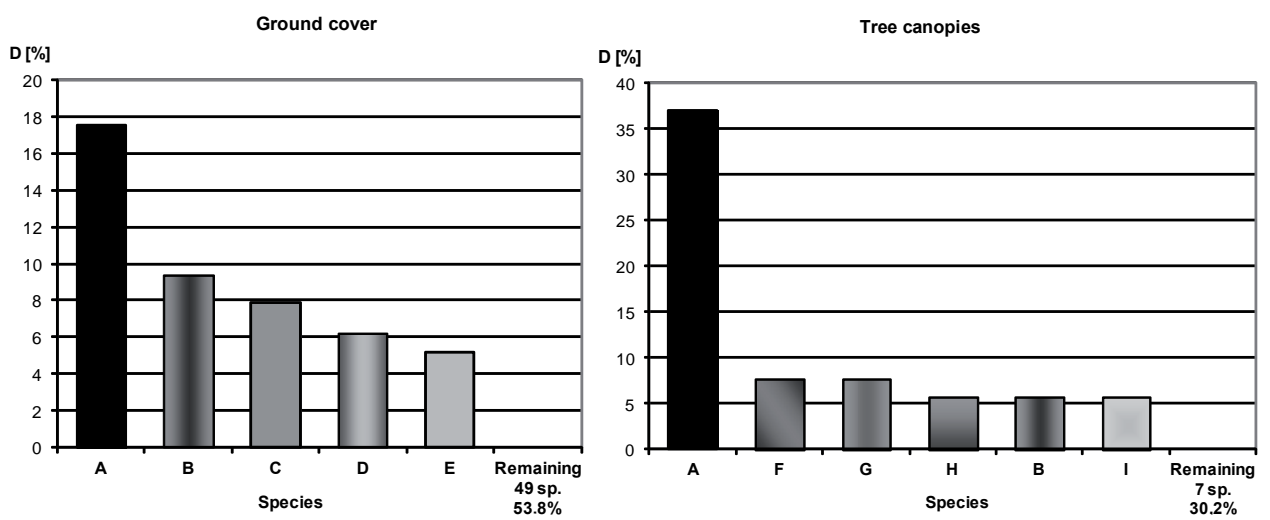

Fig. 2. Dominance patterns in bee assemblages collected in the mixed coniferous forest (BM) in the Suchedniów-Oblęgorek Landscape Park; A - Apis mellifera, B - Bombus pascuorum, C - Bombus lucorum, D - Andrena haemorrhoa, E - Bombus bohemicus, F - Andrena fucata, G - Bombus terrestris, $\mathbf{H}$ - Andrena cineraria, $\mathbf{I}$ - Bombus pratorum. 
They were mostly bumble bees and the honey bee together accounting for $84.7 \%$ of the assemblage. Dominant species were Apis mellifera (28.2\%), Bombus lucorum (17.2\%), B. sylvarum (9.1\%), B. pascuorum $(8.2 \%)$, B. bohemicus $(7.3 \%)$ and B. pratorum (5.5\%) (Fig. 5). The index of species diversity was 3.56 , and the index of evenness was 0.78 (Tab. 3 ).

Tree canopies - Catches in the canopy layer yielded only one species from the family Andrenidae (Andrena cineraria) and four species from the family Apidae (Bombus lucorum, B. pascuorum,

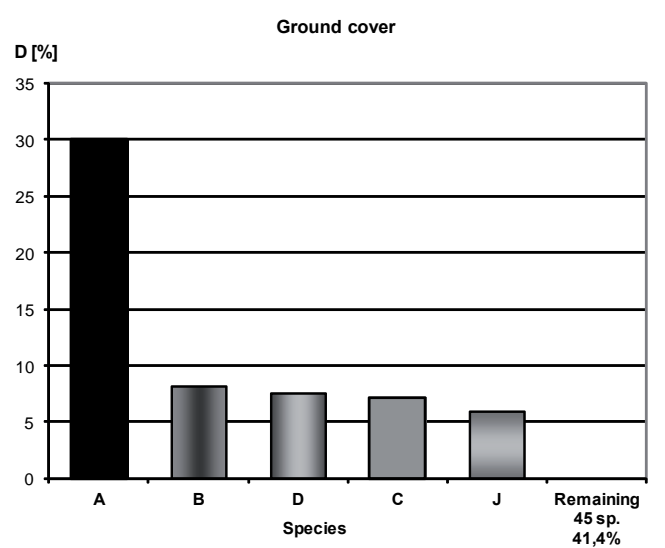

B. pratorum and Apis mellifera). The abundance of bees was also low, with 18 individuals captured (Tab. 1, 2). The five species were classified as eudominant (B. pratorum and $A$. mellifera) or dominant (A. cineraria, B. lucorum and B. pascuorum) (Fig. 5). The H' and J' indices were at their lowest in this layer, amounting to 1.74 and 0.75 , respectively (Tab. 3 ).

Fraxino-Alnetum, riparian forest (LG)

The bee assemblage in this habitat was made up of 22 species representing 6 families. A total of 121 individuals were captured (Tab. 1, 3). The abundance of bees

Fig. 3. Dominance patterns in bee assemblages collected in the mesic coniferous forest (BS) in the SuchedniówOblęgorek Landscape Park; A - Apis mellifera, B - Bombus pascuorum, C - Bombus lucorum,

D - Andrena haemorrhoa, I - Bombus pratorum, $\mathbf{J}$ - Colletes cunicularius, $\mathbf{K}$ - Andrena subopaca.
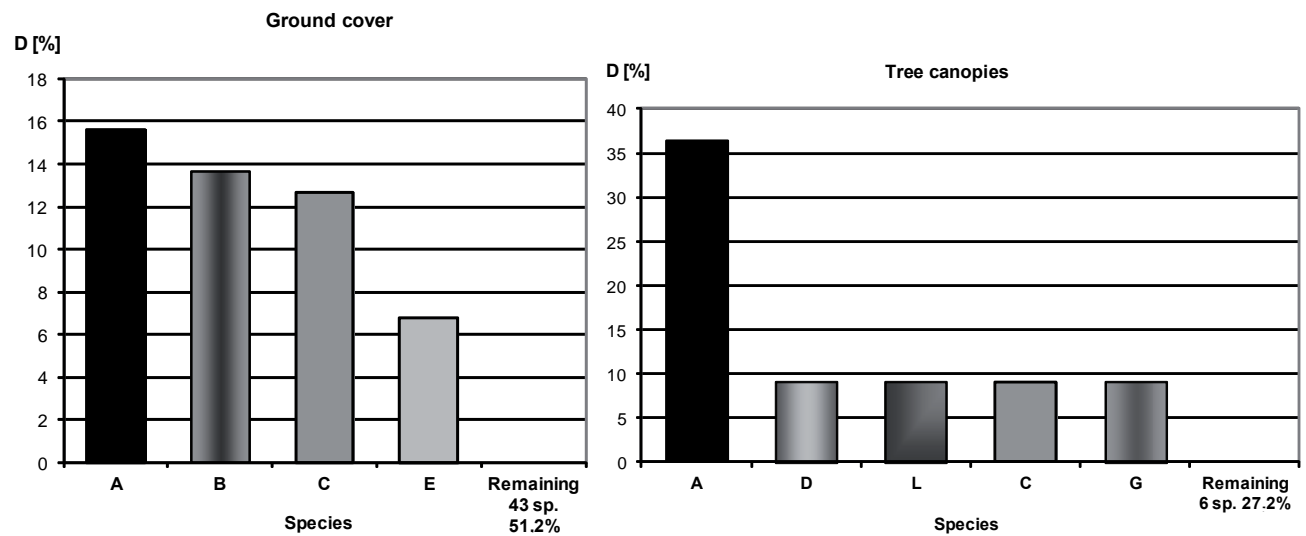

Fig. 4. Dominance patterns in bee assemblages collected in the oak-hornbeam forest (GR) in the SuchedniówObleggorek Landscape Park; A - Apis mellifera, B - Bombus pascuorum, C - Bombus lucorum,

D - Andrena haemorrhoa, E - Bombus bohemicus, G - Bombus terrestris, L - Lasioglossum subfasciatum. 
was the lowest there, across all habitats studied. The most numerous family was Apidae (10 species, 93 individuals) (Tab. 1, 2). The H' and J' indices were 3.59 and 0.57 , respectively (Tab. 3 ).

Ground cover - The bees captured in this layer belonged to 22 species (Tab. 3). Among the 104 individuals, there was a predominance of Apidae: Apis mellifera (28.8\%), Bombus lucorum $(9.6 \%)$, B. pratorum $(7.7 \%)$, B. rupestris $(7.7 \%)$, and $B$. pascuorum $(6.7 \%)$ as well as Macropis europaea (7.7\%) from the family Melittidae (Fig. 6). These species

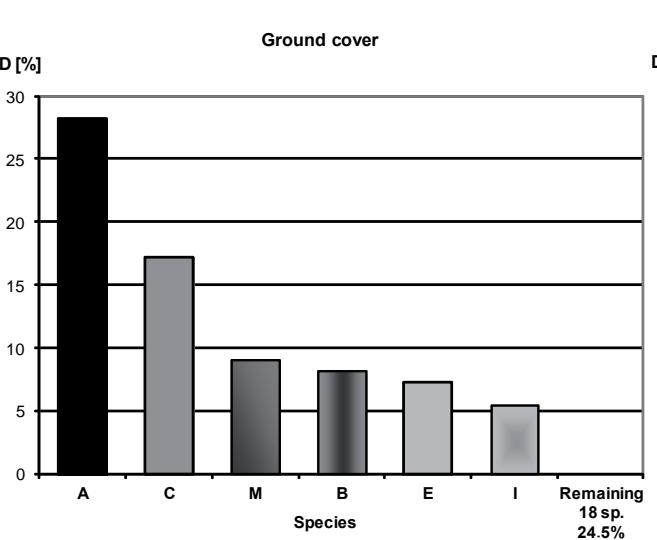

altogether accounted for $68.2 \%$ of the assemblage. The H' index reached a value of 3.66, while the index of evenness was 0.82 (Tab. 3).

Tree canopies - There were 17 individuals representing 8 species (Tab. 3). Eudominant species were Apis mellifera (53\%) and Bombus lucorum (11.8\%), and dominant species were Andrena nitida (5.9\%), Osmia rufa (5.9\%), B. hortorum (5.9\%), B. hypnorum $(5.9 \%)$, B. pascuorum $(5.9 \%)$ and $B$. pratorum $(5.9 \%)$ (Fig. 6$)$. The index of species diversity was 2.29 , and the index of evenness was 0.76 (Tab. 3).

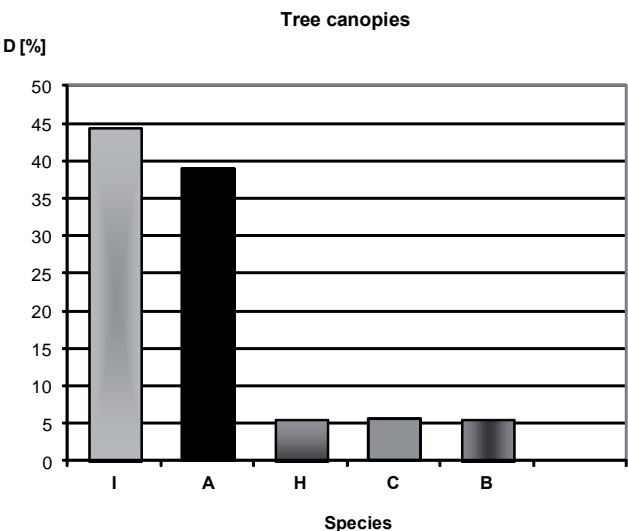

Fig. 5. Dominance patterns in bee assemblages collected in the fir forest (BJ) in the Suchedniów-

Oblęgorek Landscape Park; A - Apis mellifera, B - Bombus pascuorum, C - Bombus lucorum,

E - Bombus bohemicus, $\mathbf{H}$ - Andrena cineraria, I - Bombus pratorum, $\mathbf{M}$ - Bombus sylvarum
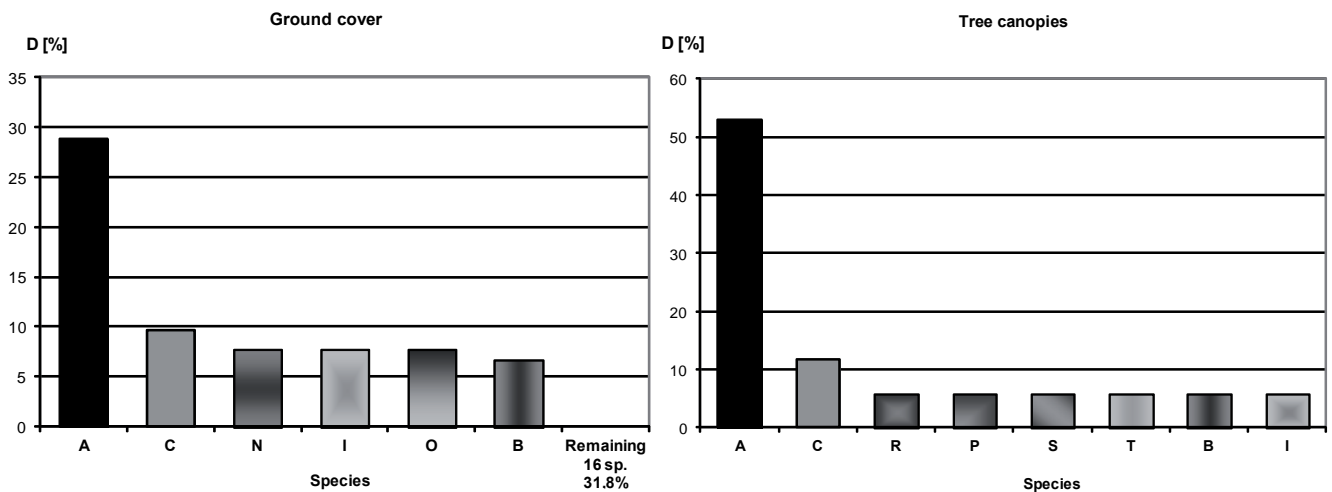

Fig. 6. Dominance patterns in bee assemblages collected in the riparian forest (LG) in the Suchedniów-Oblegorek Landscape Park; A - Apis mellifera, B - Bombus pascuorum, C - Bombus lucorum,

I - Bombus pratorum, $\mathbf{N}$ - Macropis europaea, $\mathbf{O}$ - Bombus rupestris, P - Osmia rufa,

$\mathbf{R}$ - Andrena nitida, $\mathbf{S}$ - Bombus hortorum, $\mathbf{T}$ - Bombus hypnorum 


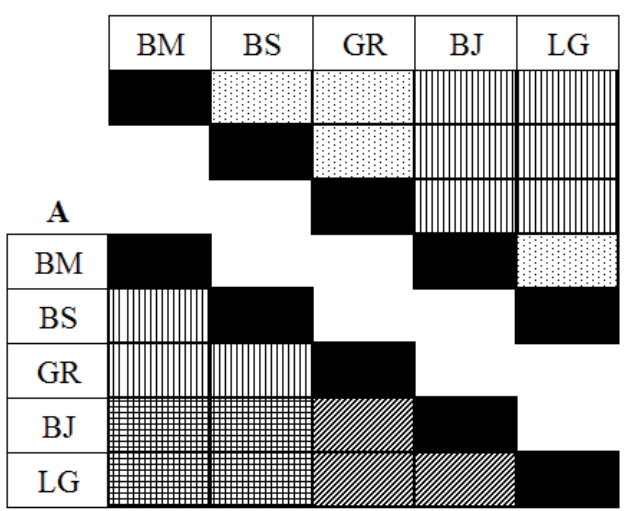

B

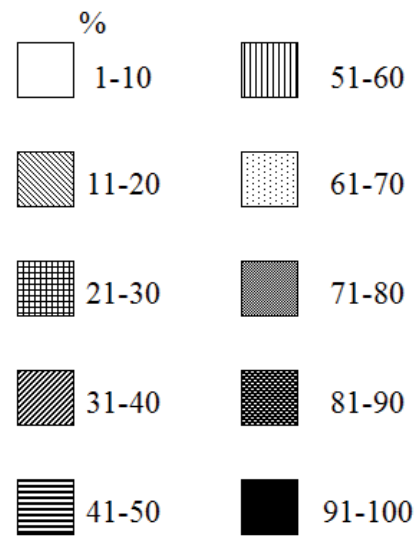

Fig. 7. Similarity between bee assemblages of forest habitats in S-OLP: A - qualitative similarity, Marczewski-Steinhaus index (MS), B - quantitative similarity, Renkonen index (Re)

The finding of bees in Moericke traps placed in two vertical layers in the study habitats indicates that bees penetrated the entire vertical range of the forests. At the same time, particular layers were penetrated more.

All traps placed on the forest floor in ground cover, collectively caught 1192 individuals $(88.8 \%)$ in all study habitats, representing 76 bee species. The percentages of total abundance at particular sites ranged from $85.9 \%$ to $90.3 \%$. Species of the genus Bombus and Andrena haemorrhoa were dominant in the low-growing herb layer. Canopy layer traps across the Park yielded 150 individuals belonging to 23 species and representing only $11.2 \%$ of all bee individuals captured during the study. The prevailing species in this layer also belonged to the genera Bombus and Andrena (Tab. 1).

An analysis of species similarity of assemblage structures (based on the MS index) found two groups. One group was comprised of the bee assemblages from the mixed coniferous forest, mesic coniferous forest, and oak-hornbeam forest, with similarity exceeding $50 \%$ (51-57\%). The other group was made up of the bee assemblages of the oak-hornbeam forest, fir forest, and riparian forest, with similarity indices of $34-39 \%$. The lowest similarity, below $30 \%$, was calculated for the remaining pairings of habitats (Fig. 7A).

The diagram presenting quantitative similarity of assemblage structure (based on the Re index) reveals decreasing values of this parameter, from the bee assemblages found at various sites. These sites were: the mixed and mesic coniferous forest sites $(70 \%)$, mixed coniferous and oak-hornbeam sites (69\%) and mesic coniferous and oak-hornbeam sites $(62 \%)$. Then there were the assemblages identified in floristically poorer habitats (fir forest and riparian forest), where the index of quantitative similarity ranged from $51 \%$ to $57 \%$ (Fig. 7B).

\section{DISCUSSION}

The finding of 76 bee species in the forests of the Suchedniów-Oblęgorek Landscape Park (S-OLP) indicates that these habitats are attractive to bees. The bee assemblages in S-OLP were mainly dominated by representatives of two genera: Bombus and Andrena. Together with their nest parasites, they accounted for $48.7 \%$ of species in the assemblage. Their individuals constituted $59.2 \%$ of the assemblage.

As regards species preferring forest habitats, those most commonly captured were Bombus lucorum, B. pascuorum, and $B$. pratorum. These species were also 
classified as dominant or subdominant in previous studies of forest communities in Poland, such as oak-hornbeam forests (Tilio-Carpinetum) or mixed and mesic coniferous forests (Leucobryo-Pinetum, Peucedano-Pinetum, CalamagrostioPinetum) (Banaszak, 1990; Pawlikowski, 1992; Banaszak and Cierzniak, 1994; Krzysztofiak, 2001). Thus, they are characteristic species closely associated with forest habitats. From the other species, Andrena haemorrhoa was also abundantly captured in the present study. Cierzniak (2003) obtained similar results in a study of bee assemblages of oak-hornbeam forests of the central part of Wielkopolska.

The study revealed that most bee individuals, chiefly of the genera Bombus and Andrena, were captured in traps placed in the ground cover. Krzysztofiak (2001), who analysed the penetration of bees into different vegetation layers in spruce-pine stands in Wigry National Park, also found the most intense penetration of these bee genera into the low herbaceous plant layer in mature stands. A study by Banaszak and Cierzniak (1994) found twice as many bee species in the herb layer than in tree canopies in oak-hornbeam and pine stands. Similar results were also obtained by Kriger and Cierzniak (2006) in a mesic coniferous forest of Bory Tucholskie National Park.

In the present study of forest communities in S-OLP, tree canopies did not support abundant bee assemblages. Most individuals preferred to use the sub-canopy layer, where vegetation density was low, from $10 \%$ in the mesic coniferous forest to $40 \%$ in the mixed coniferous forest, oakhornbeam forest and riparian forest, the bees were able to move fast in that zone. Kriger and Cierzniak (2006) state that bees captured in tree canopies use gaps and large spaces between trees to move into adjacent areas in search of food. Fooddriven migrations are common among bees in forest habitats in view of the insufficient supply of food in this biotope. Kriger and Cierzniak (2006) caught approximately
$20 \%$ of all individuals in the canopy layer of a Leucobryo-Pinetum mesic coniferous forest in Bory Tucholskie. Krzysztofiak (2001) found as little as 5\% of all individuals in a spruce-pine stand in Wigry National Park.

The results of the present study indicate that each study habitat was characterised by different values of species richness, abundance, and species diversity and evenness indices. An analysis based on the values of the $\mathrm{S}, \mathrm{H}^{\prime}$ and $\mathrm{J}$ ' indices revealed the presence of two groups of assemblages: a structurally-rich group where these indices reached high values and a group characterised by a poorer structure and lower values of S, H', J'. The former group, with a diversified species composition (47-55 species), high abundance (227-457 individuals), and high values of the H' (4.27-4.75) and J' (0.68-0.76) indices, comprised the bee assemblages from the mesic and mixed coniferous forest sites and the oak-hornbeam site (Tab. 3). The latter group, consisting of the assemblages from the fir forest and riparian forest sites, was characterised by poorer species richness (22-24 species), low abundance (121-129 individuals), and low values of the H' (3.48-3.59) and J' (0.56-0.57) indices. The same patterns were observed for bee assemblages captured in the different layers, i.e. ground cover and tree canopies, in each study habitat (Tab. 3).

Abundance and species richness as well as species diversity and evenness were found to be lower in the riparian and fir forest habitats than in the mesic and mixed coniferous forest and oak-hornbeam forest sites. Qualitative and quantitative similarity was also seen to decrease from the bee assemblages in the mesic and mixed coniferous and oak-hornbeam forest habitats to those in the fir and riparian forest sites. For bees, the low attractiveness of the riparian and fir forest habitats was related to the spatial structure of the stand and species composition of ground cover, with decreasing abundance of flowering plants and attractive nesting sites. 
Pawlikowski (1985) states that the food base is a determinant of habitat attractiveness for bees. Other equally important factors include physical factors, such as the microclimate, and a type of substrate that promotes nesting. It appears that both a dwindling food base and habitat conditions (e.g. substrate moisture levels), which changed in the sequence of plant communities presented above, might have influenced the abundance and species richness of bee assemblages. Similar conclusions were drawn by Kosior and Fijał (1992) in their study of bees of the Zamość region. They analysed the structure of bee assemblages in open, semiopen (ecotone), and forest habitats to find that the degree of organisation of these assemblages (reflected in high values of $\mathrm{S}, \mathrm{H}$ ', and J' indices) was lowest in forest habitats and increased in open and more sun-exposed areas.

In view of the attractiveness of the Suchedniów-Oblęgorek Landscape Park and the diversity of habitats in this area, studies of bee assemblages are being continued there.

\section{REFERENCES}

Banaszak J. (1987) - Pszczoły (Hymenoptera, Apoidea) wybranych zespołów roślinnych Wielkopolskiego Parku Narodowego. Bad. fizjogr. Pol. Zach., 35: 5-23.

Banaszak J. (1990) - Pszczoły (Apoidea) grądów i dąbrów świetlistych Niziny Mazowieckiej. Zesz. nauk. WSP, Bydgoszcz, 8: 23-35.

Banaszak J. (2004) - Pszczoły (Apidae), in: W. Bogdanowicz, E.Chudzicka, I. Pilipiuk, E. Skibińska (ed.). Fauna Polski. Charakterystyka i wykaz gatunków, Muzeum i Instytut Zoologii PAN, Warszawa, pp. 346-362.

Banaszak J., Cierzniak T. (1994) - Spatial and temporal differentiation of bees (Apoidea) in the forests of Wielkopolski National Park, Western Poland. Acta Univ. Lodz., Folia Zool., 2: 3-28.

Banaszak J., Jaroszewicz B. (2009) - Bees of the Białowieża National Park and adjacent area. NE Poland (Hymenoptera: Apoidea, Apiformes). Pol. pismo entomol., 78: 281-313.
Banaszak J., Plewka T. (1981) - Apoidea (Hymenoptera) Kampinoskiego Parku Narodowego. Fragm. faun., 25, 24: 435-452.

Bąk J. (2003) - Trzmiele (Bombus Latr.) i trzmielce (Psithyrus Lep.) (Hymenoptera, Apidae) w wybranych fitocenozach Suchedniowsko-Oblęgorskiego Parku Krajobrazowego. Pradnik 13: 235-244.

Cierzniak T. (2003) - Ekologia pszczół w dynamicznym kręgu zbiorowisk grądowych. Wyd. Akad. Bydgoskiej, Bydgoszcz.

Dylewska M. (1966) - The Apoidea of the Babia Góra Mountain. Acta zool. cracov., 11 (5): 111-179.

Dylewska M., Noskiewicz J. (1963) Apoidea of the Pieniny National Park. Part II. Colletidae, Andrenidae, Halictidae, Melittidae, Apidae (Nomada SCOP.). Acta zool. cracov., 13: 477-532.

Enghoff H., Nielsen E. S. (1978) - An U.T.M. base map of the Western Palearctic Region for mapping of faunistic data. Entomol. Meddr., 46: 71-72.

Kondracki J. (2002) - Geografia regionalna Polski, PWN, Warszawa.

Kosior A., Fijał J. (1992) - Analiza faunistyczno-ekologiczna owadów pszczołowatych Apoidea województwa zamojskiego. Stud. Ośr. Dok. Fizjogr., 20: 13-52.

Kriger R., Cierzniak T. (2006) - Zmiany sukcesyjne zgrupowań pszczół (Apoidea) w borach Leucobryo-Pinetum w Parku Narodowym Bory Tucholskie, in: J. Banaszak, K. Tobolski (ed.). Park Narodowy Bory Tucholskie u progu nowej dekady. Wyd. Uczeln. UKW w Bydgoszczy, Bydgoszcz, pp. 319-345.

Krzysztofiak A. (2001) - Struktura zgrupowań pszczół (Apoidea, Hymenoptera) w różnowiekowych drzewostanach świerkowososnowych Wigierskiego Parku Narodowego. Zesz. nauk. Akad. Bydgoskiej, Stud. Przyr., 15: 113-215.

Marczewski E., Steinhaus H. (1959) - O odległości systematycznej biotopów. Zast. Mat., 4: 195-203.

Michener C. D. (2007) - The Bees of the World, John Hopkins University Press, Baltimore-London. 
Mirek Z., Piękoś-Mirkowa H., Zając A., Zając M. (2002) - Flowering plants and pteridophytes of Poland - a checklist. Krytyczna lista roślin naczyniowych Polski, Szafer W. Institute of Botany, Pol. Acad. Sci., Kraków.

Moericke V. (1951) - Eine Farbfalle zur Kontrolle des Fluges von Blättläusen, insbesondere der Pfirsichblattlaus, Myzodes persicae (Sulz.). Nachrbl. Dtsch. Pflzchutzd., 3: 23-24.

Oertli S., Müller A., Dorn S. (2005) - Ecological and seasonal patterns in the diversity of a species-rich bee assemblage (Hymenoptera: Apoidea: Apiformes). Eur. J. Entomol., 102: 53-63.

Pawlikowski T. (1985) - Zgrupowania dzikich pszczołowatych (Hymenoptera, Apoidea) na kserotermicznych siedliskach wydmowych Kotliny Toruńskiej. Stud. Soc. Scient. Tor., 10, 4: 1-57.

Pawlikowski T. (1990) - Funkcja zespołów pszczołowatych w różnowiekowych monokulturach sosnowych Kotliny Toruńskiej. Wyd. SGGW-AR, 42: 184-191.

Pawlikowski T. (1992) - Struktura zespołów pszczołowatych (Hymenoptera, Apoidea) na obszarach leśnych Kotliny Toruńskiej. Rozprawy UMK, Torun.
Pielou E. C. (1966) - Species diversity and pattern - diversity in the study of ecological succesion. J. Theor. Biol., 10: 370-383.

Renkonen O. (1938) - Statistisch-ökologische Untersuchungen über die terrestische Käferwelt der finnischen Bruchmoore. An. Zool. Soc., 6: $1-231$.

Romer E. (1949) - Regiony klimatyczne Polski. Pr. Wroc. Tow. Nauk., Ser. B. 16.

Ruszkowski A., Ruszkowski J. (1998) - Słownik polskich nazw owadów. Cz. I, Instytut Sadownictwa i Kwiaciarstwa - Oddział Pszczelnictwa, Puławy.

Shannon C. E., Weaver W. (1963) The mathematical theory of communication, University Illinois Mi, Urbana.

Tuell J. K., Isaacs R. (2009) - Elevated pan traps to monitor bees in flowering crop canopies, Entomol. Exp. Appl., 131: 93-98.

Witkowski Z. (1975) - Ekologia i sukcesja ryjkowców (Coleoptera, Curculionidae) łąk kośnych okolic Zabierzowa, PWN, Warszawa.

\title{
PRZESTRZENNE ZRÓŻNICOWANIE ZGRUPOWAŃ PSZCZÓŁ (HYMENOPTERA: APOIDEA: APIFORMES) W ZBIOROWISKACH LEŚNYCH SUCHEDNIOWSKO-OBLĘGORSKIEGO PARKU KRAJOBRAZOWEGO
}

\author{
Bąk-Badowska J.
}

\author{
S t r e s z c z e n i e
}

Celem badań prowadzonych w latach 2004-2005, od kwietnia do października było scharakteryzowanie zgrupowań pszczół (Apiformes) w zróżnicowanych fitosocjologicznie zbiorowiskach leśnych Suchedniowsko-Oblęgorskiego Parku Krajobrazowego. Do odłowu zastosowano metodę pułapek barwnych Moerick'ego.

Strukturę każdego zgrupowania określano: liczbą prób (n), liczbą gatunków (S), liczbą osobników (N), dominacją (D), ogólnym zróżnicowaniem gatunkowym (H') oraz równocennością gatunkową (J'). Do jakościowego porównania wyróżnionych zgrupowań posłużono się wskaźnikiem Marczewskiego-Steinhausa (MS), a podobieństwo ilościowe badano za pomocą wskaźnika Renkonena (Re). 
$\mathrm{Na}$ pięciu powierzchniach badawczych odnotowano 76 gatunków pszczół, wśród których dominowali przedstawiciele rodzin Apidae (28 gat., 900 os.) i Andrenidae (20 gat., 222 os.). Należały do nich: Apis mellifera (24,5\%), Bombus lucorum $(9,1 \%)$, B. pascuorum $(8,8 \%) \mathrm{i}$ Andrena haemorrhoa $(5,4 \%)$. Wskaźniki różnorodności gatunkowej H' i równocenności J' osiągnęły najwyższe wartości w borze mieszanym (BM), odpowiednio 4,75 i 0,76 a najniższe w borze jodłowym (BJ), wynoszące 3,48 i 0,56. Podobieństwo jakościowe i ilościowe struktury zgrupowań spadało począwszy od środowisk boru mieszanego, świeżego i grądu do środowisk o uboższym składzie florystycznym i niesprzyjających warunkach do gniazdowania, czyli boru jodłowego i łęgu. W pułapkach umieszczonych na dnie lasu w runie, stwierdzono więcej osobników i gatunków pszczół - 1192 os. (88,8\%) i 76 gat., niż w warstwie koron drzew - 150 os. (11,2\%) i 23 gat. Dotyczyło to wszystkich środowisk leśnych S-OPK.

Słowa kluczowe: Apiformes, struktura zgrupowań, środowiska leśne, SuchedniowskoOblęgorski Park Krajobrazowy, rozmieszczenie pionowe. 